\title{
Digitalizing Islamic Philanthropy in Overcoming Post-pandemic Economic Turbulence
}

\author{
Muhammad Ainul Yaqin ${ }^{*}$, Chairina Mazaya ${ }^{1}$, and Diina Auliya ${ }^{1}$ \\ ${ }^{1}$ UIN Raden Mas Said Surakarta
}

\begin{abstract}
The COVID-19 pandemic has resulted in a recession in Indonesia. Islamic philanthropy is a solution offered by Islamic economics in an effort to overcome the impact of economic turmoil due to the COVID19 pandemic. Islamic philanthropic institutions need to innovate, one of which is through digitalizing aid-raising (zakat, infaq, alms). This study aims to determine public interest in the philanthropic movement and the role of digitalization of Islamic philanthropy in reducing the impact of the economic recession in society. This study uses a qualitative descriptive approach with the object of research is the ACT (Quick Response Action) in Surakarta. The data obtained were sourced from observations, interviews and related literature studies. Research informants came from donation institutions (ACT), donors and recipients of donations. The results showed that during the pandemic, people's motivation to share increased. This positive interest, coupled with the role of digitalizing donation payments, has made it easier for the public to pay for donations. This momentum has proven to trigger the optimization of fundraising for humanitarian aid donations in helping affected communities, so as to reduce the potential for economic turmoil by maintaining the stability of people's purchasing power.
\end{abstract}

Keywords: digitalization, economic turbulence, ZIS

\section{Introduction}

COVID-19 is a disease caused by the SARS-CoV 2 virus and has been spread almost all over the world. The World Health Organization (WHO) explains that Coronavirus (Cov) is a virus that infects the respiratory system. This viral infection called COVID-19 (Prameswati \& Malikatin, 2021). Based on data from the Indonesian Ministry of Health, the development of COVID-19 cases in Indonesia Wuhan started on December 30, 2019 where the Wuhan City Health Committee issued an "urgent notice on the treatment of pneumonia of unknown cause". The spread of the Corona virus is very fast, even across countries. So far, there are 188 countries that have been confirmed to be infected with the Corona virus, including Indonesia. The spread of the Corona virus has a fairly large impact on the Indonesian economy, both in terms of trade, investment and tourism (Nasution et al., 2020).

The COVID-19 outbreak has the potential to change the economic order marked by changes in the trade map, and resulted in the cessation of various business fields. It is certain that global trade performance will be disrupted due to the slow improvement in manufacturing performance. Coupled with the logistics distribution line which is also disrupted, the negative impact. Inevitably it will hit the Indonesian economy in the near future

* Corresponding author: muhammadyaqin52@gmail.com 


\section{$A I \overline{I E B} \quad$ Annual International Conference \\ on Islamic Economics and Business, 2021}

(Alwandi \& Muchlisoh, 2020). The economic impact due to the increasing spread of COVID19 can be felt, starting from the panic buying phenomenon, the free fall of the stock price index, the weakening of the Rupiah exchange rate against the United States Dollar (USD), sluggish industrial processing (manufacturing) activities, and ultimately the impact on slowing growth economy (Zuraya, 2020). In conclusion, the COVID-19 pandemic has also had a very significant impact on the state of the Indonesian economy.

Indonesia officially experienced a recession because economic growth in the third quarter of 2020 was still contracting. According to the Central Statistics Agency (BPS), Indonesia's economic growth was recorded at minus $3.49 \%$ yoy in the July-September period. Head of BPS Suhariyanto stated, "Cumulatively Indonesia's economic growth from the first quarter of 2020, the second quarter of 2020 and the third quarter of 2020 experienced a contraction of $2.03 \%$. In the second quarter of 2020 there was minus $5.32 \%$. yoy because of the pressure from this pandemic." The impact of the economic recession in Indonesia is very pronounced and the effect is domino. For example, when investment plummets during a recession, a significant impact on economic turmoil automatically results in the loss of several jobs or massive layoffs (Ratriani, 2020). The following is data on Indonesia's economic recession before the pandemic and after the pandemic.

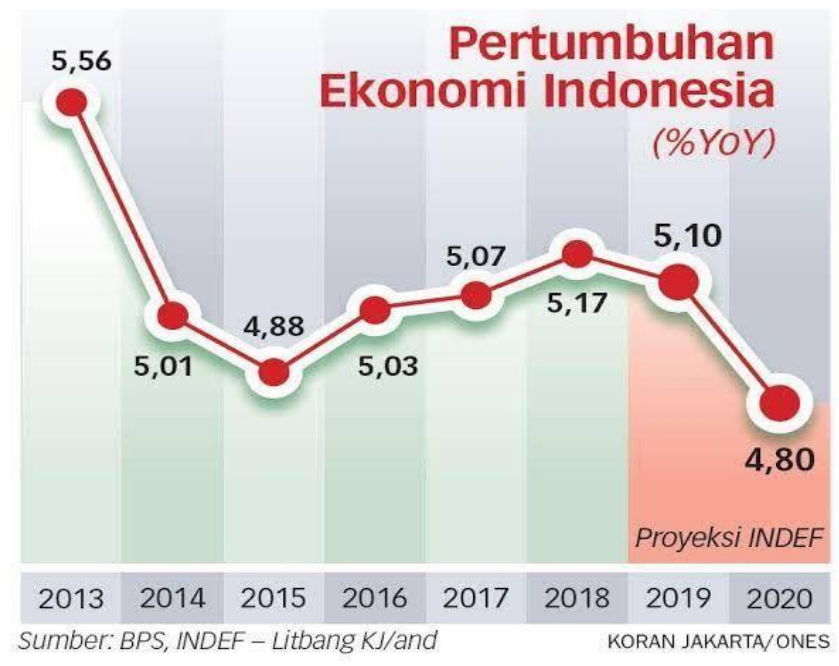

Fig 1. Data on Economic Growth in Indonesia before and after the pandemic

The spread of COVID-19 can be viewed from two different economic perspectives: different, namely supply and demand. On the demand side, the COVID-19 pandemic will significantly reduce consumption, travel and transportation activities, and increase transportation and trade costs. Judging from the supply or supply, happened decrease in labor productivity, decrease in investment and financing activities, anddisruption of the global supply chain (global value chain). There is a high probability that consumption, consumption behavior society will change automatically due to the spread of COVID-19. Public less likely to engage in travel or tourism activities and more likely to increase consumption of basic needs that are considered important to anticipate restrictions on human freedom of movement. Overall, consumption will tend to decreased due to price distortions due to the high cost of transportation and logistics of goods. In the manufacturing sector, several key sectors in Indonesia will also be affected by the spread COVID-19 causing massive layoffs. With Thus, it can be concluded that people's purchasing power is decreasing and most people people lose their jobs (Wahyunti, 2020). 


\section{$A \bar{C} \overline{I E B} \quad$ Annual International Conference \\ on Islamic Economics and Business, 2021}

The rise of Covid-19, on the other hand, has actually inspired the enthusiasm of the community to carry out ZIS with the aim of helping each other. In 2020, Indonesia even won the title of the most generous country in the world and managed to maintain pThe position until 2021 (Foundation, 2021). One of these predicates can be obtained from the realization of zakat collection which continues to increase even in the midst of a pandemic. Based on data obtained from Pusaks Basnaz, zakat funds collected in 2019 amounted to Rp. 10.2 trillion and an increase of $30 \%$ by 2020 (Anshory et al., 2021).

Various government efforts have been made to help various groups affected by Covid-19 so that the recession is reduced so that people's purchasing power is maintained. Various efforts have been made by the government, the community must also empowering each other so that every level of society can survive during the pandemic. However, the problem of distributing ZISWAF funds (Zakat, Infaq, Shadaqah and Waqaf) So far not evenly (Hamdani, 2020a; Mohamed \& Shafiai, 2021; Suradi \& Hafidz, 2021). Management of zakat, infaq and shadaqah as well as waqf that often occurs in community has not been managed properly, both in terms of organizational management and distribution. The management that has been carried out so far is still in the form of receiving zakat consumptive and some phenomena that tend to appear every year waiting ZISWAF giving from generous people and happens continuously. though ZISWAF is Islamic philanthropy which is very important in life. discussion These two things are very intensively carried out among Muslims, even the government has officially issued and stipulated Law Number 23 of 2011 concerning Islamic Law management of zakat and Law number 41 of 2004 concerning waqf. moreover, ZISWAF is not just a practice which is a form of obedience to Allah's rules and manifestations faith in Allah (hablum minallah dimension), but also as an instrument poverty and equitable distribution of economic growth (hablum minannas) (Yuliana et al., 2020). If the management of ZISWAF can be fair and If carried out in a sustainable manner, the country's poverty rate can be reduced. Because of that good, centralized and well-coordinated ZISWAF management is the key solve economic problems in the midst of this pandemic (Sholihah \& Suhendar, 2021). Therefore, it is very important to conduct research and provide a solution to the problem of managing ZISWAF funds, especially during the pandemic this COVID-19.

Various approaches have been taken to evaluate the innovation strategy of digital-based philanthropic institutions in overcoming economic turmoil. One of the instruments used is the Theory of Reason Action (theory of reasoned action. This theory assumes that behavior is determined by the individual's desire to perform or not to perform a certain behavior) (Fishbein \& Ajzen, 1975). In this regard, the theory of action of reason can encourage someone to take reasonable actions such as philanthropy. So, the use of the theory of action can influence someone to do ZIS, just as during this pandemic the number of people doing ZIS is increasing. Therefore, this study uses a theory of reason action approach to see the extent to which a person's motivation in doing ZIS is in economic instability during the pandemic.

\section{Literature Review}

This theory publishes the theory of reasoned action or what is known as the theory of reasoned action. This theory explains that behavior and intentions are two different things. Behavioral intention is only an intention, while intention or intention is the desire to perform a behavior. The theory of reasoned action explains that humans generally behave consciously, where they take into account the information that is already available, and implicitly or explicitly also takes into account the implications of the actions taken. This theory is based on the assumption that a person's intention to perform a certain behavior is a direct 


\section{$A I \overline{C E B}$ Annual International Conference \\ on Islamic Economics and Business, 2021}

determinant of that action or behavior. By limiting unforeseen events, humans are expected to act according to their intentions (Fishbein \& Ajzen, 1975).

\subsection{Digitization}

Since the 1980s, the trend of digitization began to be discussed, when home computers were introduced to the consumer market, this made information more open and consumers could easily access the latest issues. Digitization makes there are no obstacles in obtaining information and provides more freedom to interact with various parties regardless of space and time. Digitization can be defined as the use of digital technology to new business models and provide new opportunities that generate value. It is a digital business and the integration of digital technology into everyday life. Digitalization is an opportunity for companies and organizations to increase their business activities. In the era of digitization and automation, many office jobs can be produced more efficiently and at lower costs. Digitization can be seen as an opportunity to improve customer relationships, business processes, create and adapt new business models. In the financial sector, digitalization is the development of work methods, scope of work and work environment. Advances in information technology and computerized systems that have evolved into digitization can make work more efficient and faster. The general consensus is that due to digitization, customers will become more independent and the work environment is changing to be more digital, which can change the entire organization. Telecommuting and working remotely from the office will be more work methods today and in the future, digital skills are becoming increasingly important and a necessity for the workforce. In the financial sector, digitalization is the development of work methods, work scope and work environment.

Advances in information technology and computerized systems that have evolved into digitization can make work more efficient and faster. The general consensus is that due to digitization, customers will become more independent and the work environment is changing to be more digital, which can change the entire organization. Telecommuting and working remotely from the office will become more and more work methods today and in the future, digital skills are becoming increasingly important and a necessity for the workforce In finance, digitalization is the development of work methods, work scopes and work environments. Advances in information technology and computerized systems that have evolved into digitization can make work more efficient and faster. The general consensus is that due to digitization, customers will become more independent and the work environment is changing to be more digital, which can change the entire organization. Telecommuting and working remotely from the office will become more and more work methods today and in the future, digital skills are becoming more and more important and a necessity for the workforce The general consensus is that due to digitization, customers will become more independent and the work environment is changing. more digital, which can change an entire organization. Telecommuting and working remotely from the office will be more work methods today and in the future, digital skills are becoming increasingly important and a necessity for the workforce The general consensus is that due to digitization, customers will become more independent and the work environment is changing to be more digital, which can transform entire organizations. Telecommuting and working remotely from the office will become more and more work methods today and in the future, digital skills are becoming increasingly important and a necessity for the workforce (Nurfalah \& Rusydiana, 2019).

\subsection{Economic Turbulence}

Economic turbulence is a phenomenon where a location or country experiences economic instability. The economic stability of a country is related to how a country controls the 


\section{$A I \overline{C E B}$ Annual International Conference \\ on Islamic Economics and Business, 2021}

economy in the short term in order to avoid the main macro diseases, namely inflation, unemployment and inequality in the balance of payments. These three problems can influence each other, so that the task of the state to maintain economic stability is not an easy task considering the complex relationship of the three factors that influence each other (Zetira \& Fatwa, 2021).

Economic stability is a basic prerequisite for the achievement of increasing people's welfare through high growth and improving the quality of growth. Economic stability is very important to provide business certainty for economic actors. Macroeconomic stability is achieved when the relationship of the main macroeconomic variables is balanced, for example between domestic demand and national output, balance of payments, fiscal revenues and expenditures, and savings and investment. Relationships don't always have to be in perfect balance. Fiscal imbalances and balance of payments, for example, remain in line with economic stability as long as they can be financed sustainably (Zetira \& Fatwa, 2021).

An unstable economy creates high costs for the economy and society. Instability will make it difficult for people, both private and household, to plan for the future, especially in the long term required for investment. A low level of investment will reduce the potential for long-term economic growth. The existence of high fluctuations in the growth of production output will reduce the skill level of workers who have been unemployed for a long time. High inflation and high fluctuations incur huge costs for society. The heaviest burden due to high inflation will be felt by the poor who experience a decline in purchasing power. High fluctuating inflation makes it difficult to distinguish price movements caused by changes in the demand or supply of goods and services from general price increases caused by excess demand. As a result, there are inefficiencies in the allocation of resources. Given the importance of macroeconomic stability for the smooth running and achievement of national development targets, the Government is determined to continue to create and strengthen macroeconomic stability. One of the directions of the macroeconomic framework in the medium term is to maintain macroeconomic stability and prevent excessive economic fluctuations The government is determined to continue to create and strengthen macroeconomic stability. One of the directions of the macroeconomic framework in the medium term is to maintain macroeconomic stability and prevent excessive economic fluctuations The government is determined to continue to create and strengthen macroeconomic stability. One of the directions of the macroeconomic framework in the medium term is to maintain macroeconomic stability and prevent excessive economic fluctuations (Zetira \& Fatwa, 2021).

Indonesia as a developing country cannot avoid economic instability. Moreover, Indonesia is still very dependent on partner countries regarding foreign trade policies, thus making Indonesia vulnerable to global economic turmoil. Indonesia has faced crises that broke the foundations of the national economy, namely the 1998 and 2008 crises (Zetira \& Fatwa, 2021).

The crisis in the exchange rate of the rupiah against foreign currencies, especially the USD that occurred since mid-1997 resulted in a crisis of public confidence in the rupiah, then towards the banking sector, and continued to the government. To reduce the pressure of rupiah depreciation, monetary policy was implemented covering various things, including widening the intervention band, limiting foreign exchange transactions by banks, changing the exchange rate system, and tightening banking liquidity. There are restrictions on transactions with non-residents with reference to experiences during the crisis, namely the rupiah is used for speculation in the domestic market (Zetira \& Fatwa, 2021).

Based on the experience of previous economic crises, the general policy directionBank Indonesia's government and monetary policies are directed at strengthening macroeconomic fundamentals, including in the form of monetary and financial stabilization to support sustainable economic growth. A low and stable price level became the main target of 


\section{$A \mathrm{IC} \quad$ Annual International Conference \\ on Islamic Economics and Business, 2021}

monetary control during this period. Improving the performance of the current account, balance of payments and state finances, as well as how to reduce the Debt Service Ratio (DSR) so that it is at a level that is considered safe by the world bank (Zetira \& Fatwa, 2021).

This is in contrast to the 2008 crisis caused by the subprime impactmortgage in America. Starting from the decline in interest rates, housing prices that continue to rise rapidly, loosening banking standards in lending, as well as the government's push to increase private home ownership have ultimately become factors that trigger an increase in credit for highrisk housing loans. Housing loans that have been taken cannot be repaid, resulting in the company not being able to repay its loans to financial institutions that provide investments. The panic caused the stock index in Jakarta to drop drastically to a level of around 1,600. Rupiah weakened to Rp 9,700/US dollar. As a result, Bank Indonesia was forced to raise the BI Rate to 9.50 percent. This policy is indeed different in direction from developed countries (Zetira \& Fatwa, 2021).

\subsection{Islamic Philanthropy}

Philanthropy is a trait for those who are willing to share, giving voluntarily to those in need. Philanthropy is an activity of service, giving, and association. These activities are carried out consciously and voluntarily as a form of expression of affection to those in need. From this definition, philanthropy can be defined as a humanitarian activity, namely inviting, collecting, and distributing assets owned to people in need on the basis of compassion for others. Those who do philanthropic activities can be called philanthropists. The study of philanthropy is also inseparable from the religious spirit. Philanthropy plays an important role in overcoming worldly problems, namely poverty, and at the same time becomes one of the elements of religious teachings about humanity and compassion (Tamim, 2016).

The diversity of philanthropic activities in Indonesia is motivated by the many ethnic groups, races, religions and cultures. Philanthropy is divided into two based on its nature, namely traditional philanthropy and modern philanthropy. Traditional philanthropy is charity-based philanthropy. This means that this philanthropic activity is based on love which is manifested in the form of giving food, clothing, shelter, medicine. In essence, this is a form of affection given for the benefit of social service (Jusuf, 2007).

The term philanthropy associated with Islam indicates the practice of philanthropy in the Islamic tradition through zakat, infaq, alms, and waqf). This term can help bring the discourse of Islamic generosity into a discourse that can reach wider issues. Not only looking at issues from the perspective of traditional discourses, such as Islamic jurisprudence and ethics, but also relating them to issues of social justice, people's welfare, civil society, public policy, good governance and professional management (Hidayat, 2019).

Islam recommends a Muslim to do philanthropy so that wealth does not only revolve around the rich. When describing philanthropy, the Qur'an often uses the terms zakat, infaq and alms which mean giving. Generosity in Islam, which includes broad dimensions of goodness such as zakat, infaq, alms, and waqf is a term that denotes the official form of Islamic philanthropy. This Islamic philanthropy system was then formulated by the jurists with a lot of reliance on the Qur'an and the Prophet's hadith regarding detailed provisions, such as the types of assets, minimum levels, amounts, and other rules. The Qur'an does not introduce the term zakat, but alms. However, in the context of discourse, the use of the term zakat (Hidayat, 2019).

Zakat is often interpreted as an obligatory expenditure of assets and one of the pillars of Islam and is based on certain calculations. Infaq often refers to gifts that are not zakat, which are sometimes larger or smaller than zakat and usually for the public interest. For example, the assistance of prayer rooms, mosques, madrasas and Islamic boarding schools. Alms 


\section{$A \mathrm{IC} \quad$ Annual International Conference \\ on Islamic Economics and Business, 2021}

usually refers to small donations given to the poor, beggars, buskers, and others. While waqf is almost the same as infaq, but has an element of lasting benefits; cannot be traded and cannot be inherited (Kasdi, 2016).

The urgency of philanthropy in Islam can be seen from the way the Qur'an emphasizes the balance between issuing zakat and enforcing prayer. After the command of zakat is clear, the Qur'an repeats the commandment of zakat 72 times and combines it with the commandment of prayer (iqam ash-salat). The word infaq with its various derivatives appears 71 times and the word alms appears 24 times which shows the meaning and activities of Islamic philanthropy. The teaching of prayer is the main pillar of Islam and the practice of zakat is considered equivalent to the implementation of prayer (Hidayat, 2019).

\section{Method}

This study is a descriptive study because it describes the public's interest in the philanthropic movement and the role of digitalizing Islamic philanthropy during the pandemic (Hamdani, 2020b). This research uses descriptive qualitative which aims to provide a detailed explanation of certain phenomena in the form of certain patterns. Therefore, the data needed are primary data and secondary data (Makhrus, 2018). Data collection is obtained through observation, interviews, and document studies (written), which are classified as primary data. While secondary data is additional information such as theory, historical information and other data that aims to complement primary data (Suharso et al., 2018). Data informants came from donation institutions (ACT), donors and recipients of donations in Surakarta City. The validity of the data in this study used triangulation techniques. Credibility test using source triangulation technique, where the researcher tests the validity of the data by inspecting the data to the same source of informants but with different techniques (Sugiono, 2015).

\section{Results and Discussion}

Based on the interviews and observations that have been made, the authors can describe the public's interest in philanthropic activities and the role of digitalizing philanthropy. In this study, the authors obtained results related to philanthropic activities during a pandemic and the role of digital philanthropy in reducing economic turmoil. The philanthropic organization (ACT) stated that there was an increase in the number of donors during the pandemic. ACT's use of digital media has a positive impact on the work programs of philanthropic institutions. The following table summarizes the results of interviews with several parties.

Table 1. Summary Of The Results Of Semi-Structured Interviews Aboutdigitalizing Islamic Philanthropy In Overcoming Post-Pandemic Economic Turbulence

\begin{tabular}{|l|l|}
\hline \multicolumn{1}{|c|}{ Period } & \multicolumn{1}{c|}{ Aspects } \\
\hline Warming up & $\begin{array}{l}\text { ACT is a philanthropic institution that focuses on humanitarian work on disaster } \\
\text { management, as well as various social activities such as distributing ZIS (zakat, } \\
\text { infaq, shadaqah) to those in need. } \\
\text { ACT is the object of the philanthropic institutions we interviewed. Muzaki in this } \\
\text { interview is Muhammad Nafis. And the mustahiq is Esa Tika. }\end{array}$ \\
\hline $\begin{array}{l}\text { Exploration of } \\
\text { present aspects }\end{array}$ & $\begin{array}{l}\text { ACT party } \\
\text { a. What media information is used to inform people who want to donate? } \\
\text { b. How is the distribution media done? } \\
\text { c. How is the difference in the number of people who donated before the } \\
\text { pandemic and after the pandemic? } \\
\text { Muzaki's side } \\
\text { a. What is your reason for making a donation? } \\
\text { b. Are there other figures/motivations that motivate you to donate? }\end{array}$ \\
\hline
\end{tabular}




\section{$A I \bar{C} \quad$ Annual International Conference \\ on Islamic Economics and Business, 2021}

\begin{tabular}{|c|c|}
\hline & $\begin{array}{l}\text { c. How is the distribution media that you do, is it through the institution or } \\
\text { directly to the mustahiq? } \\
\text { d. After the pandemic that caused this recession, is your desire to pray } \\
\text { increasing? } \\
\text { Mustahiq party } \\
\text { a. What are your views on the donation programs carried out by various existing } \\
\text { institutions? } \\
\text { b. How do you feel after receiving a donation? } \\
\text { c. How do the economic conditions before the pandemic and after the pandemic } \\
\text { compare? } \\
\text { d. How will the pandemic affect your income and consumption patterns? }\end{array}$ \\
\hline $\begin{array}{l}\text { Exploration of } \\
\text { future aspects }\end{array}$ & $\begin{array}{l}\text { ACT is very good at developing the potential for donation innovations through } \\
\text { digitization. Which makes it easier for someone to make a donation. So my hope in } \\
\text { the future is that all parties who are in need and are affected by covid } 19 \text { or various } \\
\text { other disasters will receive assistance according to their needs and channeled to the } \\
\text { right people. }\end{array}$ \\
\hline Finish & $\begin{array}{l}\text { This pandemic does not reduce people's intention to donate, but motivates more } \\
\text { people to donate. Now, ACT uses digital media in campaigning, collecting and } \\
\text { distributing donations. Digitization really helps ACT in running philanthropic } \\
\text { programs. So that it can help reduce the impact of the pandemic. One of the muzaki } \\
\text { stated that during the pandemic the desire to donate has increased and the } \\
\text { digitization used by philanthropic institutions has made it easier to distribute } \\
\text { donations. } \\
\text { With this pandemic, more and more people are experiencing economic } \\
\text { difficulties, so many people are more motivated to donate. In addition, digitization } \\
\text { makes it easier for muzaki to make donations. ZIS during a pandemic can help } \\
\text { various groups to meet their needs and restore people's consumption patterns as } \\
\text { before the pandemic. } \\
\text { During the pandemic, people's incomes are reduced so their needs are not met. } \\
\text { The existence of philanthropic activities helps in meeting needs and can even set } \\
\text { aside money to meet other needs. From the results obtained, it can be seen that } \\
\text { during the pandemic the level of public interest in philanthropic activities increased. } \\
\text { In line with the theory of reasoning, motivation from within can encourage someone } \\
\text { to carry out philanthropic activities during an increasing pandemic. Digitization } \\
\text { helps optimize philanthropic activities. Thus, massive philanthropic activities are } \\
\text { able to maintain the level of public consumption. So that indirectly the economic } \\
\text { turmoil can be overcome and reduce the impact of the recession. }\end{array}$ \\
\hline
\end{tabular}

Based on the results of interviews, the reason people engage in philanthropic activities comes from conscious personal desires. Seen from the reasons people share, this is in line with the theory of reasoned action. The theory of reasoned action explains that humans generally behave consciously, where they take into account the information that is already available, and implicitly or explicitly also takes into account the implications of the actions taken.(Fishbein \& Ajzen, 1975). In the results of the interview, it was obtained about the public's interest during the pandemic. What was found was an increase in philanthropic activity during this pandemic. This is in accordance with research related to increasing community enthusiasm for magic. Based on data obtained from Pusaks Basnaz, zakat funds collected in 2019 amounted to Rp. 10.2 trillion and an increase of 30\% by 2020 (Anshory et al., 2021).

In the midst of this increase, the digitalization carried out can increase the funraising carried out by philanthropic institutions. According to theory, advances in information technology and computerized systems that develop into digitization can make work more efficient and faster (Nurfalah \& Rusydiana, 2019). The theory is in accordance with the 


\section{$A \mathrm{IC} \quad$ Annual International Conference \\ on Islamic Economics and Business, 2021}

results of research interviews. The philanthropic institute said that digitalization has increased efficiency in Islamic philanthropic activities.

The results of the interview found that activities by philanthropic institutions were able to slightly reduce the impact of this pandemic so as to maintain community economic stability. The importance of macroeconomic stability for the smoothness and achievement of national development targets. One of the directions of the macroeconomic framework in the medium term is to maintain macroeconomic stability and prevent excessive economic fluctuations (Zetira \& Fatwa, 2021). One of the efforts to maintain economic stability and reduce the impact of economic turbulence can be done through philanthropic activities. For this reason, Islamic philanthropic institutions need to increase their movement in an effort to reduce the impact of the recession.

The results of interviews that have been analyzed with theory prove an increase in public interest in philanthropic activities during this pandemic. Then digitization carried out by philanthropic institutions has a positive influence in making Islamic philanthropic activities massive. These two findings can be a reference for Islamic philanthropic institutions to further digitize and innovate. To reduce the impact of economic economic turbulence, Islamic philanthropic institutions can do this through the use of digital media. The well-rotated roots of the economic pyramid (society) are expected to be able to reduce the effects of the pandemic on the economy, namely reducing economic turbulence.

\section{Conclusion}

The COVID-19 pandemic has caused economic turmoil. Despite experiencing economic instability, public interest in philanthropic activities is increasing. This encourages Islamic philanthropic institutions to innovate digitalization in the form of donations or ZIS through social media platforms. This study uses a reasoned action theory approach. The object of this research is the Surakarta branch of ACT (Quick Response). Based on observations made with the Surakarta branch of ACT, it is stated that the number of people doing Islamic philanthropy is increasing. Mustahik said that during the pandemic interest in Islamic philanthropy increased with the information that was very easy to access through social media. A philanthropic institution cannot be separated from fundraising and fundraising. In today's digital age, ACT also innovates with digitalization to improve its ability to carry out philanthropic activities. With this digitization, the acquisition of donations is increasing so that the distribution takes place more massively. Indirectly can reduce the impact of the recession that occurred.

This study still has limitations in data collection. For further research, it can be directed to dig deeper data, both with qualitative data and quantitative data. As a suggestion for other philanthropic institutions to take the same steps to take advantage of the pandemic momentum in increasing philanthropic activities.

\section{References}

Alwandi, \& Muchlisoh. (2020). Karakteristik Pertumbuhan Ekonomi dan Sektor Basis Provinsi di Indonesia pada Masa Pandemi Covid-19. Seminar Nasional Official Statistics, 1. https://doi.org/10.34123/semnasoffstat.v2020il.516

Anshory, Hamani, A. A., \& Adhiningsih, S. M. (2021). Strategy of Zakat Collection During Covid-19 Pandemic: Muzakki Perception. Baznas Center of Startegic Studies, 1(12). https://doi.org/10.33648/ijoaser.v4i1.101

Fishbein, \& Ajzen. (1975). Belief, Attitude, Intention and Behavior: An Introduction to Theory and Research. Addison. 


\section{$A \overline{I C B}$ Annual International Conference \\ on Islamic Economics and Business, 2021}

Foundation, C. A. (2021). CAF World Giving Index 2021: A Global Pandemic Special Report. Charitied Aid Foundation.

Hamdani. (2020a). Prinsip-Prinsip Kepemilikan Harta dalam Islam. El-Mal : Jurnal Kajian Ekonomi Dan Bisnis, 1(2). https://doi.org/10.47467/elmal.v1i2.180

Hamdani, L. (2020b). Zakat Blockchain: A Descriptive Qualitative Aproach. Jurnal Ekonomi Dan Bisnis, 4(2), 492-502. https://doi.org/10.14421/EkBis.2020.4.2.1270\%0A492

Hidayat, A. (2019). Platform Donasi Online Dan Filantropi Digital. Jurnal Universitas Airlangga, 1-16.

Jusuf, C. (2007). Filantropi Modern Untuk Pembangunan Sosial. Sosio KOnsepsia, 12(1), 74-84.

http://ejournal.kemensos.go.id/index.php/SosioKonsepsia/article/download/621/261

Kasdi, A. (2016). Filantropi Islam Untuk Pemberdayaan Ekonomi Umat (Model Pemberdayaan ZISWAF di BMT Se-Kabupaten Demak). IQTISHADIA Jurnal Kajian Ekonomi Dan Bisnis Islam, 9(2), 227-245. https://doi.org/10.21043/iqtishadia.v9i2.1729

Makhrus. (2018). Social Media Based Islamic Philanthropy To Develop Philanthropy Awareness In Indonesia. Advances in Social Science, Education and Humanities Research, 231, 365-368. https://doi.org/10.2991/amca-18.2018.100

Mohamed, \& Shafiai. (2021). Islamic Agricultural Economic Financing Based on Zakat, Infaq, Alms and Waqf In Empowering The Farming Community. Iqtishaduna: Jurnal Ilmiah Ekonomi Kita, 10(1). https://doi.org/10.46367/iqtishaduna.v10i1.334

Nasution, D., Erlina, E., \& Muda, I. (2020). Dampak Pandemi Covid-19 Terhadap Perekonomian Indonesia. Jurnal Benefita, 5(2). https://doi.org/10.22216/jbe.v5i2.5313

Nurfalah, I., \& Rusydiana, A. S. (2019). Digitalisasi Keuangan Syariah Menuju Keuangan Inklusif: Kerangka Maqashid Syariah. Ekspansi: Jurnal Ekonomi, Keuangan, Perbankan Dan Akuntansi, 11(1), 55. https://doi.org/10.35313/ekspansi.v11i1.1205

Prameswati, L. N., \& Malikatin, N. I. (2021). Program Pendampingan Pembelajaran Bagi Siswa Sekolah Dasar Kota Kediri di Masa Pandemi. Jurnal Pasoepati, 3(1). http://ejournal2.undip.ac.id/index.php/pasopati

Ratriani, V. (2020, November). Apa itu Resesi Ekonomi dan Dampaknya yang Resmi dialami Indonesia? Nasional.Konton.Co.Id.

Sholihah, N., \& Suhendar, F. (2021). Ziswaf Role in The Formation of Justice of The Muslim Redistributive. International Journal of Nusantara Islam, 9(1). https://doi.org/10.15575/ 10.15575/ijni.v9i1.11768

Sugiono, P. D. (2015). Memahami Penelitian Kualitatif. Alfabeta.

Suharso, P., Sarbini, S., \& Sumarsono, D. (2018). The Philanthropy Culture in the Local Area: The Role Study of Philanthropy Institution after the Termination of PNPM in Boyolali Regency. E3S Web of Conferences, 68, 1-10. https://doi.org/10.1051/e3sconf/20186801012

Suradi, \& Hafidz, A. (2021). Optimalisasi Pengelolan Dana Ziswaf dalam Meningkatkan Kesejahteraan Ekonomi Anggota Koperasi Syariah Benteng Mikro Indonesia Cabang Cikupa, Tanggerang. Management of Zakat and Waqf Journal (MAZAWA), 2(2), 170179. https://doi.org/10.15642/mzw.2021.2.2.170-179

Tamim, I. H. (2016). Filantropi dan Pembangunan. Jurnal Community Development, 1(1), 121-136. https://journal.iainkudus.ac.id/index.php/comdev/article/viewFile/2578/1998

Wahyunti. (2020). Peran Startegis UMKM dalam Menopang Perekonomian Indonesia di Tengah Pandemi Covid-19. Jurnal Ekonomi Syariah, 3(2). http://ejournal.iaimbima.ac.id/index.php/jesa/article/view/554

Yuliana, Rostartiona, Teguh, Saleh, \& Apriani. (2020). Pengelolaan Dana ZISWAF Masjid Pintar di Desa Kota Daro II, Kecamatan Rantau Panjang, Kabupaten Ogan Ilir. 


\section{$A T C$ Annual International Conference \\ on Islamic Economics and Business, 2021}

Sricommerce: Journal of Sriwijaya Community Services, 1(1). https://doi.org/10.29259/jscs.v1i1.7

Zetira, A., \& Fatwa, N. (2021). Optimalisasi Penghimpunan Zakat Digital Di Masa Pandemi. JURNAL EKONOMI, 8(2), 228-237. https://doi.org/10.34308/eqien.v8i2.241

Zuraya, N. (2020). Tiga Dampak Besar Pandemi Covid-19 Bagi Ekonomi Republik Indonesia. Republika. Co. Id. 